\title{
Designing A Language Lesson: Pedagogical and Linguistic Perspectives
}

\author{
Didin Nuruddin Hidayat \\ UIN Syarif Hidayatullah Jakarta \\ didin.nuruddin@uinjkt.ac.id
}

\begin{abstract}
Designing a language lesson is a challenging task for teachers. In order to have a good language lesson, teachers cannot just rely on the textbook. They need at least to develop the lesson from the textbook or even to design their lesson. Teachers also need to consider how they are going to apply the lesson planned in the classroom. Another consideration would be to integrate the specific language skill and element with the other skills. This is essential in order to achieve the utmost results of teaching and learning. This paper discusses a language lesson in the area of grammar - Used To - designed by the author. The lesson is not only intended to expose learners to the structure and rules of grammar but also allow learners to practice the grammar in use. Hence, the developed grammar lesson aimed to improve the communicative competence of the learners. Considering the broad aspect of teaching analysis, the present article focuses on the application of the lessons in the classroom, the aspects of language skills covered, as well as the linguistic foundation for the exercises. It is hoped that this article can provide insights into language educators in developing grammar lessons that cater to the considerations of pedagogical and linguistic perspectives.
\end{abstract}

\author{
ARTICLE HISTORY \\ Received 30 September 2018 \\ Accepted5 October 2018
}

\section{KEYWORDS}

Grammar; language lesson; pedagogy; linguistic

\section{INTRODUCTION}

Successful language learning is measured by a person's proficiency in four language skills. These include two types of receptive skills (listening and reading) and the other two types of productive skills (speaking and writing. In addition to the four language skills mentioned above, the success of language learning also depends on the acquisition of other language elements. These include grammar, vocabulary, and pronunciation. Grammar, for instance, is essential regarding bringing one's speaking proficiency to a higher level. In order to communicate artistically with a varied range of structures, a greater depth of grammatical understanding is necessary (Debata, 2013). Similarly, grammatical knowledge helps a speaker to organize and express the idea in his or her mind and thus improves the development of fluency (Hinkel\&Fotos, 2002). 
Nonetheless, developing a grammar lesson that can improve learners' communicative fluency is not an easy task to do. Several reasons are hindering the realization. One of the obstacles is the inconsistency of grammar role in language learning. Grammar was claimed to be an essential part of language teaching, and thus other elements of languages were undermined (Richards \&Renandya, 2002). However, the trend shifted in line with the notion of communicative competence which stressed that grammatical competence was only one part of a more significant element in communicative competence and hence became less important to emphasize (Canale\& Swain, 1980). Departing from the point mentioned above, it is necessary to shift the teaching of traditional grammar in that it focuses only on the structures and rules into that of focusing on the teaching of grammar focusing on its use as well.

Developing English materials for language learning is an essential element In English language teaching. Teachers can choose readily available from the internet, coursebooks, videotapes and so forth. However, there is also an opportunity for teachers to construct their English materials. Despite some disadvantages of constructing own teaching materials, such as general lack of quality and time consuming, there is also some evidence of advantages. Among others are that teachers own materials allow for contextualization, individual needs, and personalization (Howard \& Major, 2004). The focus of this article is to develop a teacher-made grammar lesson which not only covers the teaching of its structures and rules, but also the one which allows learners to use the grammar as part of their effort in improving their communicative competence.

\section{LITERATURE REVIEW}

In the past few decades, scholars have attempted to explore principles and strategies in developing English learning materials. One example was proposed by Graves (2000). She proposed a series of principles in designing materials. She further described the process into several meaningful units: (1) assessing needs, (2) formulating goals and objectives, (3) developing materials, (4) designing an assessment plan, (5) organizing the course, and (6) conceptualizing content. She emphasized that there is no hierarchy in the process and no sequence in the 
accomplishment. A material developer may start where to begin the process. However, an important principle should be taken into consideration: the process needs to make sense.

Another way to develop English learning materials was proposed by Tomlinson (2012). He asserted that the principles for developing ELT materials should cover the following. The first is that to acquire a higher level of acquisition, learners need to be exposed to a rich, meaningful and comprehensible language input. In order to achieve that, a variety of text types and genres with different topics, themes, events, locations has to be prepared. Further, Tomlinson (2012) advocated the importance of engaging learners with the language learning experience, both regarding effective and cognitive factors. This could be one effective way in maximizing learners with language in use. It is suggested that activities such as predicting, connecting, interpreting and evaluating should be encouraged to stimulate learners higher order thinking skills. The next principle of materials development is that materials should be interesting for learners, relevant to the context of teaching and enjoyable to explore. This is crucial regarding achieving positive effects from learning a language and thus allowing a greater possibility of achieving communicative competence. The final crucial principle of ELT materials development is that a course developer is required to prepare the opportunities for learners to practice the language. By preparing so, learners have ample opportunities to achieve the intended communicative purposes. Hall (1995) added that the materials should also be directed towards student-centeredness, instead of teacher-centeredness. Plenty opportunities for learners to engage with each other should be considered when developing learning materials.

\section{METHOD}

This language lesson was intended to develop a new product of language learning materials focusing on the specific grammatical structure of Used To. Hence, the 
focus covers not only the theory of grammar but also expands a language learning product that can be employed in English teaching and learning process. The grammar lesson aimed to support student understanding and its practical language use regarding used to + infinitive. The lesson targeted students with a pre-intermediate level of English proficiency. Their age ranged from 13-15 years old, studying at junior high school level of education.

The objectives of the lesson are that students understand the structure and form of used to. In addition to that, inductive grammar teaching will be exposed to the students aiming to create a student-centered learning atmosphere, adhering to one of the principles of materials development proposed by Tomlinson (2012). Ample opportunities for students to practice the grammar are also provided to allow opportunities for them to use the grammar in meaningful communication. The supporting materials in this grammar lesson are taken from several sources: internet websites and teacher hand-outs. The lesson also integrates the micro skills (grammar and pronunciation) and macro skills (speaking). Materials produced should ideally provide learners with opportunities to integrate language skills authentically and to become competent at integrating extra-linguistic factors (Howard \& Major, 2004).

\section{FINDINGS AND DISCUSSION}

The approach applied in developing this grammar lesson is Communicative Language Teaching where the lesson is intended to introduce the students not only to the rules of language usage but also to the language use. This means that the students are introduced to the form of Used To; moreover, they were given more opportunity to practice the form in real situations. Larsen-Freeman (1986) stated that Communicative Language Teaching aims to make the students communicatively competent. In order to achieve this, it is essential for the students to be equipped with the linguistics form, meaning, and function. This lesson attempts to meet those criteria (The complete lesson can be found in the Appendix).

Initially, the teacher tries to engage the students by showing a picture of him when he was a student. The teacher then models the sentence examples such as "when I was a student, I used to have long hair but now I have short hair" and writes the sentence 
on the board. The students repeat what the teacher says. Several other sentences are also provided, and the students do the repetition. Hubbard, Jones, Thornton, and Wheeler (1983) define this technique as structural items where grammatical points are introduced in the form of examples or model sentences while textbook writers recognize this technique as pattern drilling. After the students start to recognize the pattern, the teacher puts picture prompts on the board. At this stage, the teacher uses substitution drills technique by pointing to the pictures and asking the students to create Used To sentences. Stevick (1982, p. 91) asserts that "if the teacher does the drill right, then he/she (1) draws on existing resource (competence) in the students to (2) produce new behavior (performance) which when rewarded by success (3) builds new resources (competence)". A substitution drill is supposed to be a systematic way of converting performance into competence where the students are guided to construct sentences of a common form. This drill will build up new resources that will enable the students to generate this pattern autonomously.

At the next procedure, the teacher explains the structure and form of Used To regarding the affirmative, negative, and interrogative forms. The teacher uses an inductive approach in explaining the grammar focus where he provides sample sentences before the grammar explanation. The purpose of giving the exposure by presenting the Used To sentences is to familiarize the students with its structure; so that, it will be easier for them to understand when the teacher explains the grammar rules. Thornbury (1999) lists several advantages of using the inductive approach. He argues that since the students can notice the rules by themselves through the sample sentences, they are more likely to fit the students' existing mental structures, which in turn will make the rules more meaningful and memorable.

Furthermore, unlike the deductive approach, which makes the passive students recipients, the inductive approach creates an active learning atmosphere where the students try to recognize the patterns by themselves. This condition will make the students more motivated and attentive during the lesson. Likewise, a study by Gorat and Prijambodo (2013) which examined the effect of the deductive and inductive approach to teaching grammar found that the latter was more effective than the former. A more recent study by Hmedan and Nafi (2016) also confirmed the 
advantages of inductive approach in teaching grammar. Their study revealed that the use of the inductive approach far outweighed the results of teaching through traditional ways of grammar teaching.

In achieving meaningful communication, there are at least two skills, which should exist and they should not be taught separately (Hinkel, 2006). Thus, providing the utmost learning opportunity for the students can be achieved by incorporating language skills. In this lesson, the micro skills (grammar and pronunciation) are integrated with the macro skills (speaking). The reason of integrating grammar with speaking is not only to give more of a chance for the students to practice the language focus but also to provide them with real speaking situations; so that, they can use the language focus in daily communication. Recent studies also show that extensive exposure in communicative interaction does not improve fluency and accuracy together unless proper balance with the linguistic input exists (Ligthbown\&Spada, 1990, cited in Hinkel, 2006). The grammar Used To, in this case, becomes the input, which builds the students' linguistic foundation. The students, after getting exposed to the language focus, will be able to produce utterances with this language input in speaking. As Harmer (2007) asserted, the more the students are exposed with the input, the more English they will learn and produce.

Furthermore, one of the main criteria in teaching pronunciation, as asserted by Hinkel (2006), is to teach pronunciation and intonation in context and conjunction with speaking skills. In this lesson, pronunciation takes its appropriate role regarding helping the students to achieve overall intelligibility as well as building the students' confidence. If they have good pronunciation, they will be more confident as they speak and thus become better speakers. The area of pronunciation taught in this lesson is intonation, especially rising intonation in Yes/No Questions. Knowles (1987) distinguishes the intonation of Wh-Questions and Yes/No Questions. WhQuestions, those beginning with a word-initial wh such as which, when, what, etc. Falling intonation should be used in questions similar to the following ones:

Which color do you like? 
How much money do you have?

On the contrary, Yes/No Questions employ rising intonation, as in the following questions:

Did you use to have short hair?

Did you use to play hide-and-seek when you were a kid?

This pronunciation practice is applied before the students have the Yes/No guessing game; so that, when the game starts, the students can pronounce Yes/NoQuestions correctly.

In the Yes/No guessing game exercise, the students should be able to construct used to in the interrogative statement, which needs sentence transformation due to the different form with the affirmative statement. Do-support transformation, a term coined by Wardhaugh (1972), should exist. Nevertheless, since used to is in the past time, auxiliary did take place. The sentence transformation is defined in the example below:

You used to watch cartoon movies

(Question) you (past) used to watch cartoon movies

(past) you used to watch cartoon movies

(past) did you use(d) to watch cartoon movies

Did (past\#) you use to watch cartoon movies

Did you use to watch cartoon movies? 
In the internet exercise, the students are asked to complete the blank form using Used To in either an affirmative or negative statement. This exercise employs computers and the internet as educational aids, which have advantages regarding providing interactive capability. Nelson (1976, cited in Kenning \& Kenning, 1983) alleges that computer has its characteristics and differs from books and tape recording. The former provides interaction with the students and is able not only to analyze the specific mistakes the students face but also to offer the understanding of the principles behind the correct solution, while the latter can only tell the rules to the students.

Below are the sample questions taken from the website:

1. The Cherokee __ (wear) clothes made from animal skins before the arrival of the Europeans.

2. When I was a kid, I (belief) there were monsters under my bed.

3. In the Middle Ages, people (eat neg.) much meat or fish.

4. You (be neg.) so nervous. What happened?

The grammatical, morphological, and syntactic analysis will be used in interpreting and segmenting the exercises. Fromkin, Rodman, Hyams, Collins, \&Amberber (2005) define morphology as the study of word formation and the internal structure of words. Besides, words consist of some elements, which are known as morphemes. Used (To) can be broken down into two morphemes, use and -ed. Use is considered as a free morpheme while $-e d$ is regarded as a bound morpheme. Yule (1996) describes free morpheme as a morpheme, which is independent and has a meaning. He further explained bound morpheme as a morpheme, which is attached to free morpheme; thus, it cannot stand by itself. Used to, as a whole, could be considered as a lexical phrase because used to is a single fixed unit. Skehan (1992, cited in Willis, 2003) explains this as 'ready-made elements and chunks which does not need to be constructed independently.'

There is a difference between the first two questions and the last two questions. The former is designed to measure whether the students understand the structure of used 
to in the affirmative form while the latter checks the students' comprehension of the negative form of used to. In the last two questions, both morphological and syntactical transformations exist. In transforming the affirmative to the negative, auxiliary did should be added after the subject, then negation not follows auxiliary did. The last transformation would be putting use to plus the plain form of the verb. Inflectional morpheme $-e d$ is deleted. Consequently, the correct answers are:

In the middle ages, people did not use to eat much meat or fish.

You did not use to be so nervous. What happened?

\section{CONCLUSION AND SUGGESTION}

To recapitulate, some factors should be considered in designing a language lesson. Firstly, a teacher ought to decide which approach and teaching techniques he or she is going to apply in the classroom. The next consideration would be integrating the language skills. In order to achieve a maximum teaching and learning result, the language skills should be taught in tandem, such as grammar, speaking, and pronunciation. Knowledge of grammar will be the source of the linguistic base in achieving the accuracy; communicative interaction and meaningful communication become the basis of speaking fluency; pronunciation takes part in attaining the overall intelligibility. The exercises, which serve as the measurement of the students' understanding, should be developed based on and in conjunction with the language skills taught.

\section{REFERENCES}

Canale, M., \& Swain, M. (1980). Theoretical bases of communicative approaches to second language teaching and testing. Applied Linguistics, 1(1), 1-47. 
Debata, P. K. (2013). The importance of grammar in English Language Teaching: A reassessment. Language in India, 13(5), 482-486.

Fromkin, V., Rodman, R., Hyams, N., Collins, P., \&Amberber, M. (2005).An introduction to language ( $5^{\text {th }}$ ed.). Melbourne: Nelson Australia.

Gorat, L. \&Prijambodo, V. (2013). The effect of using deductive approach and inductive approach in teaching English to students on their conditional sentence mastery.Magister Scientiae, 33, 78-92.

Hall, D. (1995). Materials production: Theory and practice. In A. C. Hidalgo, D. Hall, \& G. M. Jacobs (Eds.), Getting started: Materials writers on materials writing (pp. 8-14). Singapore: SEAMEO Regional Language Center.

Harmer, J. (2007).The practice of English language teaching ( $4^{\text {th }}$ ed.). Essex: Pearson Education Limited.

Hinkel, E., \&Fotos, S. (Eds.) (2002). New perspectives on Grammar teaching in second language classrooms. Mahwah, NJ: L. Erlbaum Associates.

Hinkel, E. (2006). Current perspective in teaching the four skills.TESOL Quarterly, 40(1), 109-131.

Hmedan, H. A. A., \&Nafi, J. S.I (2016). The effect of using inductive and deductive methods on $7^{\text {th }}$-grade students' achievement in Grammar in Bethlehem District and their attitudes toward EFL.International Journal of Education and Social Sciences, 3(9), 38-53.

Howard, J., \& Major, J. (2004).Guidelines for designing effective English Language Teaching Materials.Retrieved from http://www.paaljapan.org/resources/proceedings/PAAL9/pdf/Howard.pdf

Hubbard, P., Jones, H., Thornton, B., \& Wheeler, R. (1983).A training course for TEFL. Oxford: OxfordUniversity Press.

Kenning, M. J., \& Kenning, M. M. (1983).An introduction to computer-assisted language teaching. Oxford: OxfordUniversity Press.

Knowles, G. (1987). Patterns of spoken English: An introduction to English phonetics. New York: Longman.

Larsen-Freeman, D. (1986). Techniques and principles in language teaching. Oxford: OxfordUniversity Press.

Richards, J., \&Renandya, W. A. (Eds.) (2002).Methodology in language teaching: An anthology of current practice. Cambridge: Cambridge University Press.

Stevick, E. (1982). Teaching and learning languages. Cambridge: CambridgeUniversity Press. 
Thornbury, S. (1999). How to teach Grammar. Essex: Pearson Education.

Tomlinson, B. (2012). Materials development for language learning and teaching.Language Teaching, 45(2), 143-179.

Wardhaugh, R. (1972). Introduction to Linguistics. New York: McGraw Hill.

Willis, D. (2003). Rules, patterns, and words: Grammar and Lexis in English language teaching. Cambridge: CambridgeUniversity Press.

Yule, G. (1996). The study of language ( $2^{\text {nd }}$ ed.). Cambridge: CambridgeUniversity Press. 